\title{
The Implication of Autoantibodies in Early Diagnosis and Monitoring of Plasmonic Photothermal Therapy in the Treatment of Feline Mammary Carcinoma
}

Asmaa M. El-Rasikh

CU Faculty of Veterinary Medicine: Cairo University Faculty of Veterinary Medicine Haithem A. M. Farghali ( $\nabla$ dr_haithem0@yahoo.com )

CU Faculty of Veterinary Medicine: Cairo University Faculty of Veterinary Medicine Hisham A. AbdelRahman

CU Faculty of Veterinary Medicine: Cairo University Faculty of Veterinary Medicine Mostafa Elgaffary

CU Faculty of Veterinary Medicine: Cairo University Faculty of Veterinary Medicine

Shaymaa Abdelmalek

CU Faculty of Veterinary Medicine: Cairo University Faculty of Veterinary Medicine Ibrahim A. Emam

CU Faculty of Veterinary Medicine: Cairo University Faculty of Veterinary Medicine Magdy A. Ghoneim

CU Faculty of Veterinary Medicine: Cairo University Faculty of Veterinary Medicine

Salah A. Selim

CU Faculty of Veterinary Medicine: Cairo University Faculty of Veterinary Medicine

\section{Research}

Keywords: Autoantibodies, cancer, mammary, C-MYC, MUC-1, P53, PCNA, plasmonic photothermal therapy

Posted Date: January 29th, 2021

DOI: https://doi.org/10.21203/rs.3.rs-153355/v1

License: (c) (1) This work is licensed under a Creative Commons Attribution 4.0 International License. Read Full License 


\section{Abstract}

Background

Last year's plasmonic photothermal therapy (PPTT) achieved great success in the treatment of feline mammary carcinoma and there is a demand for developing an easy, cheap, rapid, sensitive, and specific tool for early diagnosis and monitoring of treatment response.

Methods

A panel of four autoantibodies (P53, PCNA, MUC-1, and C-MYC) was evaluated in serum of 11 normal cats and 34 cats diagnosed with mammary tumors before, during, and after the treatment using Enzyme-Linked Immunosorbent Assay (ELISA) assay. Out of the 34 cats, 15 did not receive any treatment, ten cats were treated with PPTT, three cats were treated by mastectomy, and six cats were treated with a combination of PPTT and surgery.

Results

The panel showed high specificity and sensitivity to mammary tumors. The panel also was efficient in the evaluation of PPTT treatment response as their values decreased significantly after three months from the end of treatment. During the PPTT treatment course, the panel values increased within a month before the appearance of secondary tumors and/or metastasis but this increase was not statistically significant. As a result of the short follow-up period in this study, the studied panel was not valid in early diagnosis of primary and/or recurrent tumors nor the evaluation of treatment response of surgery alone or combination therapy. Cats treated with PPTT monotherapy showed the highest survival rate followed by cats treated with combination therapy then cats treated with mastectomy.

Conclusion

The studied autoantibodies panel can be used to evaluate PPTT treatment response after three months of the end of treatment and may be efficient in early diagnosis of primary tumors, secondary tumors, recurrence, or metastasis.

Trial registration

All animals were handled in accordance with the Association for Assessment and Accreditation of Laboratory Animal Care and Office of Laboratory Animal Welfare guidelines. All animal experiments were approved by the Institutional Animal Care and Use Committee (CU-IACUC) Cairo University (code: CU II F 9 16). The animal experiments were carried out after the owner's permission. Written informed consent was provided by each cat owner for the treatments.

\section{Background}

Feline mammary tumor is the counterpart of human breast cancer and this is due to the great similarity founded between them at the cellular and molecular levels. This provides an essential conceptual tool for 
basic and clinical research, grantee a better understanding of breast cancer biology, and consequently allowing a more accurate stratification of patients for targeted therapies [1].

The interaction between the immune system and cancer cells proceeds in three phases: elimination; equilibrium; and escape, which are referred to as the "three Es" of cancer immunoediting. During the 'elimination' phase, the immune system may succeed in destroying all tumor cells. If that does not happen, it may still be able to control tumor growth but not eradicating it completely. This phase is referred to as the 'equilibrium' phase. Finally, due to selection pressure from the immune system, some cancer cells develop enough resistance that they can escape the immune system, leading to a failure of immune-mediated cancer control which is called the 'escape' phase [2]. The release of proteins from tumors triggers an immune response in cancer patients. These tumor antigens or also called tumor-associated antigens (TAAs) arise from several mechanisms including tumor-specific alterations in protein expression, mutation, folding, degradation, or intracellular localization. Responses to most tumor antigens are rarely observed in healthy individuals, making the response itself a biomarker that betrays the presence of underlying cancer. It is not known if the antibodies to tumor-derived proteins reflect underlying immunosurveillance of cancer or have an impact on the clinical outcome of the disease [3]. The real usefulness of the TAAs as circulating tumor markers in the management of breast cancer has been questioned because of the low diagnostic sensitivity for early disease prior appearance of clinical manifestation and prior recurrence or even metastasis. Moreover, their role in monitoring treatment responses through different stages of tumorigeneses, particularly after completion of therapy, remained unavailable [4].

Circulating antitumor markers antibodies exhibit increased levels in very early cancer stages in sera prior TAAs can be detected as their production precede clinical confirmation of a tumor by several months or years [5]. Autoantibodies (AAbs) that arise against the TAAs are present in the circulation of people with various forms of a solid tumor before TAAs can be detected, and these molecules can be measured up to 5 years before symptomatic disease [6]. Among 196 specific tumor-associated AAbs, the most frequently studied with a diagnostic value was the P53 antibody followed by autoantibodies against MUC-1, HER2, cyclin B1, NY-ESO-1, HSP60, and C-MYC. Combinations of tumor-associated AAbs showed higher diagnostic sensitivity than individual autoantibodies but single autoantibodies usually showed higher specificity [7]. Until now, a wide range of AAbs has been identified. Although several studies present hopeful preliminary results, there is a need to validate AAbs' signature for biomarker researches in the clinic [8].

The p53 protein is involved in several critical pathways including cell cycle arrest, apoptosis, DNA repair, and cellular senescence, which are essential for normal cellular homeostasis and genome integrity maintenance. Alteration of the TP53 gene or posttranslational modification in p53 protein can alter its response to cellular stress. The molecular archaeology of the TP53 mutation spectrum generates hypotheses concerning the etiology and molecular pathogenesis of human cancer [9]. Mucin 1, cell surface-associated (MUC-1) also called polymorphic epithelial mucin (PEM) and epithelial membrane antigen (EMA) is a member of the mucin family which is a large, heavily transmembrane glycoprotein. The MUC-1 is generally expressed at low levels by normal simple secretory epithelial tissues, its overexpression is often associated with most carcinomas and in particular by breast cancers and correlates with high metastatic and poor survival [10]. The MYC is a family (C-MYC, L-MYC, and N-MYC) of regulator genes and proto-oncogenes that code for 
transcription factors as a nuclear phosphoprotein that plays a role in cell cycle progression, apoptosis, and cellular transformation which regulate up to $15 \%$ of all human genes. Amplification of these genes is frequently observed in numerous human and animal cancers [11]. The C-MYC function is associated with specific molecular subtypes of breast cancer, its overexpression confers resistance to therapy and its activation has been widely reported in breast cancer progression [12]. Proliferating cell nuclear antigen (PCNA) is a non-histone nuclear protein associated with mitotic activity and tumor grade [13].

Plasmonic photothermal therapy (PPTT) is a cancer therapy in which gold nanorods are injected into the tumor before exposure to near-infrared light causing localized cell death (apoptosis) which applied in dogs and cats suffering from naturally occurring mammary gland carcinoma by professor Mostafa A El-Sayed group and the treated cases showed no recurrence or metastasis for one year after treatment $[14,15]$. However, the mechanism by which PPTT induces complete ablation of small tumors and immune mechanisms underlying the prevention of in situ recurrence and distant metastasis induced by local PPTT therapy are unknown also the complex interaction between PPTT, breast cancer, and the immune system. Usually innate and adaptive immunity play a key role in the elimination of breast cancer. Adaptive immunity exerts its anticancer activity through the production of AAbs against the TAAs and cytotoxic effector CD 8+ lymphocyte triggered by cell-mediated immune response [16]. However the role of AAbs in protecting against breast cancer remains elusive, but their validity in diagnosis, early diagnosis, prognosis, predictions, and monitoring of treatment response acquire raising interest and numerous publications reported the validity of AAbs assay in early diagnosis of breast cancer [17].

The main target of the present investigation was to investigate the validity of AAbs assay in early diagnosis, prognosis, prediction, and monitoring of different treatments (PPTT monotherapy treatment efficiency was evaluated during different stages of carcinogenesis either pre, during, and post-completion of treatment and prior recurrences, surgery only treatment and combination treatment of surgery and PPTT were evaluated before and after a period of surgery.

\section{Methods}

\section{Animals}

The animals were admitted to the clinic of the Department of Surgery, Anesthesiology, and Radiology, Faculty of Veterinary Medicine, Cairo University, Egypt from August 2018 to February 2020. All cats did not receive any treatment for mammary tumor before. All animals were handled in accordance with the Association for Assessment and Accreditation of Laboratory Animal Care and Office of Laboratory Animal Welfare guidelines. All animal experiments were approved by the Institutional Animal Care and Use Committee, Cairo University (CU-IACUC) (code: CU-IACUC-II-F-9-16). The animal experiments were carried out after the owner's permission. Written informed consent was provided by each cat owner for the treatments. Treatment was applied with a high standard of veterinary care. Mammary tumors were diagnosed through physical examination of cats. The initial tumor dimensions were measured in all animal groups using calipers. Additional measurements of tumor dimensions were made with each cycle of PPTT treatment. Cats were also examined by X-ray (Fisher, Berlin, Germany). The radiographic setting factors were $58-70 \mathrm{kVp}, 10$ 
$\mathrm{mAs}$, and a $90 \mathrm{~cm}$ focal spot film distance. The radiographic exposures were conducted dorsoventrally and right laterally.

Table 1. Animal groups

\begin{tabular}{|lllll|}
\hline $\begin{array}{l}\text { Group } \\
\text { No. }\end{array}$ & $\begin{array}{l}\text { Group } \\
\text { name }\end{array}$ & Animal groups & $\begin{array}{l}\text { Cases } \\
\text { No. }\end{array}$ & $\begin{array}{l}\text { Lung } \\
\text { metastasis }\end{array}$ \\
\hline 1 & H & Apparently healthy cats & 11 & 0 \\
\hline 2 & TN & $\begin{array}{l}\text { cats with variable sizes of the mammary tumor and did not } \\
\text { receive any treatment for the tumor }\end{array}$ & 15 & 5 \\
\hline 3 & TP & $\begin{array}{l}\text { cats bearing mammary tumors smaller than } 10 \mathrm{~cm}^{2} \text { treated } \\
\text { with PPTT monotherapy }\end{array}$ & 10 & 2 \\
\hline 4 & TS & $\begin{array}{l}\text { cats bearing mammary tumors larger than } 10 \mathrm{~cm}^{2} \text { treated } \\
\text { with surgery only }\end{array}$ & 3 & 1 \\
\hline 5 & TSP & $\begin{array}{l}\text { cats bearing mammary tumors larger than } 10 \mathrm{~cm}^{2} \text { treated } \\
\text { with the combination of surgery and PPTT }\end{array}$ & 6 & 2 \\
\hline & $\begin{array}{l}\text { Total animal population } \\
\text { Cat }\end{array}$ & $\begin{array}{l}45 \\
\text { cat }\end{array}$ & 10 cats \\
\hline
\end{tabular}

(TN) tumor-no treatment, (TP) tumor-PPTT alone, (TS) tumor-surgery alone, (TSP) tumor-surgery, and PPTT.

\section{Treatments}

In the TP group, the number of PPTT cycles was correlated to the size of the mammary tumor [14]. Gold nanorods (AuNRs) with an average size of $27( \pm 5) \times 6( \pm 1) \mathrm{nm}$ (length $\times$ width) coated with Methoxy polyethylene glycol thiol (mPEG-SH) and Arg-Gly-Asp (RGD) peptides and $808 \mathrm{~nm}$ diode laser with a power of $0.5 \mathrm{~W} / \mathrm{cm}^{2}$ and a spot size of around $5.6 \mathrm{~mm}^{2}$ were kindly gifted by prof. Mostafa A. El-Sayed; Laser Dynamics Laboratory, School of Chemistry and Biochemistry, Georgia Institute of Technology, USA. In the TS group, the mastectomy operations were performed as previously described [18]. Mastectomy operations were conducted by members of the surgery, anesthesiology, and radiology department of the Faculty of Veterinary Medicine, Cairo University. Under general injectable anesthesia, each animal was pre-medicated with atropine sulphate ( $1 \%, 0.05-0.1 \mathrm{mg} / \mathrm{kg}$ b. wt.; ADWIA Co. S.A.E., Cairo, Egypt) and xylazine $\mathrm{HCl}(1$ $\mathrm{mg} / \mathrm{kg}$ b. wt.; Xyla-Ject $2 \%{ }^{\circledR}$, ADWIA Co. S.A.E.), and then anesthesia was induced using ketamine $\mathrm{HCl}(10-$ $15 \mathrm{mg} / \mathrm{kg}$ b. wt.; Ketalar ${ }^{\circledR}$, Sigma-Aldrich Co.) and maintained by ketamine $\mathrm{HCl}$ [19]. In the TSP group, the treatment was performed according to previously described [15].

\section{Samples}

Serum samples were collected from cats treated with PPTT monotherapy (TP) before, during, and after the course of treatment. While the serum samples from cats treated with mastectomy only (TS) or combination therapy (TSP) were collected before surgery and within one month and a half after the surgery. All collected serum samples were immediately stored at $-40{ }^{\circ} \mathrm{C}$ until use. 
The first step was the standardization of indirect Enzyme-Linked Immunosorbent Assay (ELISA) by checkerboard titration as described in previous studies [20 - 23] using the following recombinant proteins as coating antigens: TP53 (ABIN1046804), MUC1 (ABIN1877158), MYC (ABIN2130698), PCNA (ABIN622005). All the antigens were purchased from Antibodies Online (https://www.antibodies-online.com/) (Germany) and are of human origin. Antigens were subjugated to Lasergene software analysis to evaluate their identity $\%$ with feline antigens [ 24 - 27] which were as the following $76.65 \%, 60 \%, 88.8 \%$, and $99.22 \%$, respectively. The checkerboard titration was conducted to optimize antigen concentration and serum dilution. Antigen concentrations were $50,25,12.5,6.25,3.125,1.5625,0.78125 \mathrm{ng} /$ well and serum dilutions were 1/40, 1/80, $1 / 160,1 / 320,1 / 640,1 / 1280,1 / 2560,1 / 5120,1 / 10240,1 / 20480$.

\section{ELISA}

The optimal antigen concentration (50 ng/well) and serum dilution (1/160) were then used for all subsequent ELISA tests and applied according to previously described in [28 - 37]. Coating of 96 well Immulon 4HBX Microtiter plates (cat. no. 3855; Thermo Fisher Scientific, USA) with antigen diluted in carbonate bicarbonate (SERVA Electrophoresis $\mathrm{GmbH}$, Germany) buffer for $2 \mathrm{~h}$ at $37^{\circ} \mathrm{C}$ then overnight at 4 ${ }^{\circ} \mathrm{C}$. Washing four times with Phosphate Buffered Saline with 0.05\% Tween ${ }^{\circledR}$ 20, pH 7.4 (PBST) (SERVA Electrophoresis $\mathrm{GmbH}$, Germany). Blocking the wells with $100 \mu \mathrm{l} /$ well by $5 \%$ skimmed milk for $2 \mathrm{~h}$ at $37^{\circ} \mathrm{C}$. Washing then adding $100 \mu \mathrm{l}$ of diluted serum samples in a duplicate manner and incubated for $90 \mathrm{~min}$ at 37 ${ }^{\circ} \mathrm{C}$ with shaking. Washing and adding of $100 \mu$ per well of diluted Goat anti-feline $\lg \mathrm{G}(\mathrm{H}+\mathrm{L})$ secondary antibody horseradish peroxidase (HRP) conjugated (cat. no. PA1-84673; Thermo Fisher Scientific, USA) according to manufacture instruction (1/10000) incubated for $90 \mathrm{~min}$ at room temperature with shaking. Washing seven times with PBST and adding $50 \mu \mathrm{l} /$ well of UltraTMB $\left(3,33^{\prime}, 5,5^{\prime}\right.$-tetramethylbenzidine) coloring reagent (cat. no.34028; Thermo Fisher Scientific, USA) according to manufacture instruction. Stopping the reaction after $15 \mathrm{~min}$ with $50 \mu \mathrm{l} /$ well of $2 \mathrm{M}$ Sulfuric acid (ADWIC, Egypt) and the absorbance was read immediately at $450 \mathrm{~nm}$ BioTek ELX808IU ${ }^{\text {TM }}$ microtiter ELISA reader (BioTek, Winooski, VT, USA).

\section{Statistical analyses}

The receiver operating characteristic (ROC) analysis was performed in SigmaPlot v14.0 (Systat Software, San Jose, CA, USA) using mammary tumor status (with tumor vs not tumor) as the binary state classification variable and AAbs values on a continuous scale as the test variable to determine the area under the curve (AUC) which is an important measure of the accuracy of the diagnostic marker. Pairwise comparisons of AUC among the four studied markers were performed using Chi-square $\left(\chi^{2}\right)$ tests. On ROC curves, sensitivity, specificity, positive likelihood ratio (LR+), negative likelihood ratios (LR-), and Youden's index $(\mathrm{YI})$ were used to evaluate the diagnostic performance of all AAbs, and these parameters were based on the methodology provided in the Epidemiology textbook [38]. The optimal cut-off values on the ROC curves were determined from YI.

Kaplan-Meier survival analyses were performed for estimation of median survival times and survival probabilities of cats in each treatment group and cats with or without metastasis. Log-rank tests were used 
to compare the survival probability among treatments and to evaluate the effect of metastasis on survival probability.

For each marker, a two-way repeated-measures analysis of variance (ANOVA) test was used to compare between first and last marker values within each treatment group (TS, TP, and TSP). At any sampling event, the total tumor area $\left(\mathrm{mm}^{2}\right)$ per each cat was calculated. A one-way repeated-measures analysis of covariance (ANCOVA) test was used to compare all measured values for each marker among treatment groups while accounting for the effect of total tumor area as a covariate.

To evaluate the efficiency of studied markers in predicting the occurrence of tumor progressive events, a twoway repeated-measures ANOVA test was used for each marker to compare the predictive and pre-predictive values among treatment groups. The evaluated tumor progressive events were secondary, recurrent tumor, and metastasis. The term "predictive" value refers to the last marker value before the appearance of the tested event while the "pre-predictive" refers to the last marker value before the predictive value.

For the repeated measures tests, data were blocked by cat ID. The Shapiro-Wilk test was utilized for normality analysis of the variables. The Tukey's Studentized Range (HSD) test was used for post-hoc analysis. All $p$ values less than 0.05 were considered statistically significant. All data were presented as the mean \pm standard error of the mean $(S E)$. Analyses were performed with SAS ${ }^{\circledR}$ version 9.4 [39].

Table 2. Include figures of some cases before and after the treatments 


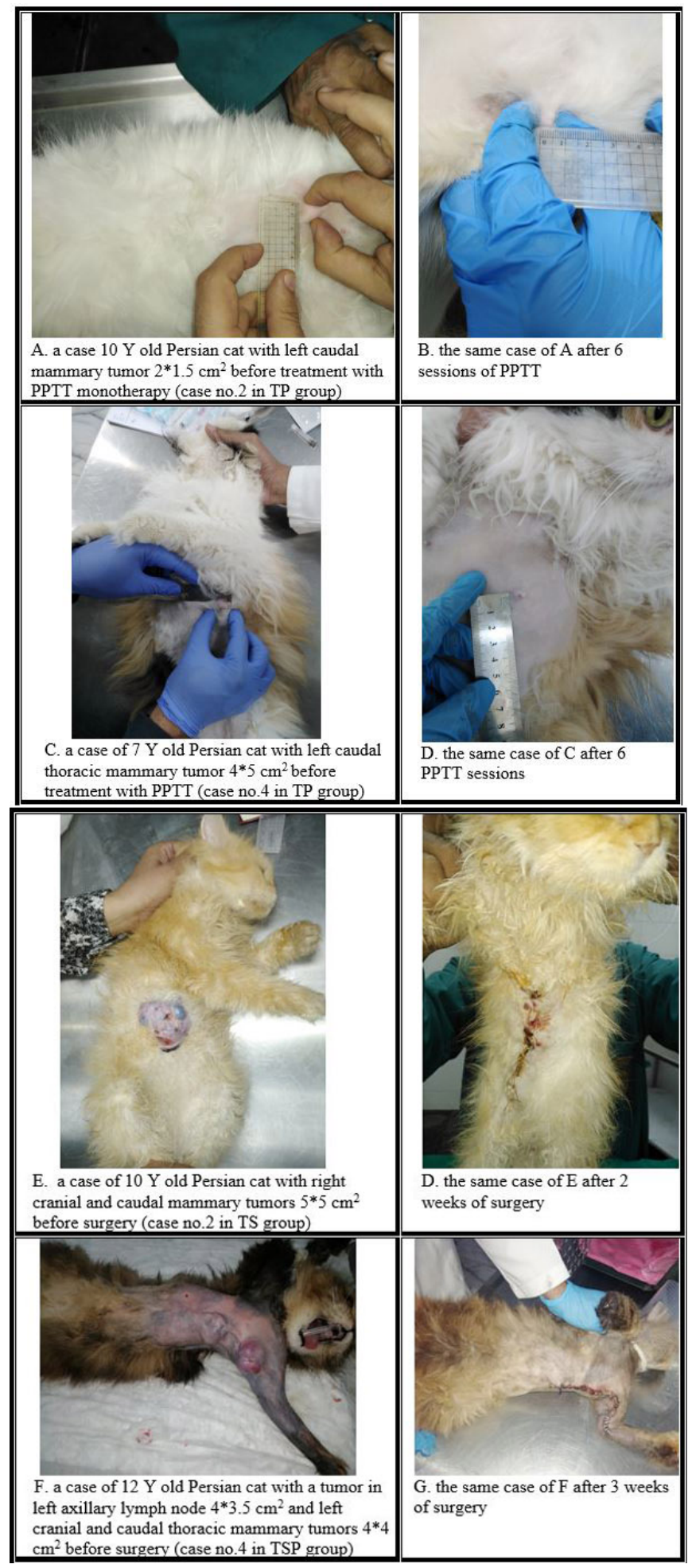

\section{Results}

Animals' responses to different treatments were shown in table 2 and the detailed data appended.

Results of ROC analysis (Table 3) showed that values of any of the four studied diagnostic markers before application of any treatment could significantly differentiate between the normal group $(\mathrm{H} ; n=6)$ and the cats diagnosed with mammary tumor (TN + TP + TS + TSP; $n=32)$. Areas under the ROC curves were not 
different among the four studied AAbs $(p>0.05)$. The highest YI values indicated the optimal cut-off values for the studied AAbs with the corresponding specificity of $100 \%$ and sensitivity above $93.7 \%$ (Table 4 ).

Table 3. Mean \pm standard error $(S E)$ of AAbs values measured for normal cats $(n=6)$ and cats diagnosed with mammary tumor $(n=32)$, the area under the receiver operating characteristic curve (AUC) $\pm S E$ for the four studied AAbs and their 95\% confidence intervals (C.I.), and $p$-value.

\begin{tabular}{|llllll|}
\hline Variable & & \multicolumn{2}{l}{ Markers } & & \\
\cline { 3 - 6 } & & PCNA & P53 & MUC-1 & C-MYC \\
\hline \multirow{2}{*}{ Mean $\pm S E$} & Normal & $0.2133 \pm 0.02$ & $0.2458 \pm 0.01$ & $0.2303 \pm 0.01$ & $0.2625 \pm 0.01$ \\
\cline { 2 - 6 } & With tumor & $0.9643 \pm 0.08$ & $1.1858 \pm 0.09$ & $1.3937 \pm 0.10$ & $0.9917 \pm 0.05$ \\
\hline \multirow{2}{*}{ AUC } & Estimate $\pm S E$ & $0.9583 \pm 0.03$ & $0.9740 \pm 0.03$ & $0.9688 \pm 0.03$ & $1.00 \pm 0.00$ \\
\cline { 3 - 6 } & $95 \%$ C.I. & $0.8931-1.024$ & $0.9219-1.026$ & $0.9075-1.030$ & $1.000-1.000$ \\
\cline { 2 - 6 } & $p$-value & 0.0004 & 0.0003 & 0.0003 & 0.0001 \\
\hline
\end{tabular}

Table 4. Optimal cut-off values of the four studied AAbs and their corresponding for sensitivity (\%), specificity (\%), negative likelihood ratio (LR-), and Youden's index (YI).

\begin{tabular}{|c|c|c|c|c|c|c|c|}
\hline \multirow[t]{2}{*}{ Marker } & \multirow{2}{*}{$\begin{array}{l}\text { Optimal Cut- } \\
\text { off }\end{array}$} & \multicolumn{2}{|c|}{ Specificity (\%) } & \multicolumn{2}{|c|}{ Sensitivity (\%) } & \multirow[t]{2}{*}{ LR- } & \multirow[t]{2}{*}{ YI } \\
\hline & & Estimate & 95\% C.I. & Estimate & 95\% C.I. & & \\
\hline PCNA & 0.314 & 100 & $\begin{array}{l}54.07- \\
100\end{array}$ & 93.75 & $\begin{array}{l}79.19- \\
99.23\end{array}$ & 0.063 & 93.75 \\
\hline P53 & 0.352 & 100 & $\begin{array}{l}54.07- \\
100\end{array}$ & 96.88 & $\begin{array}{l}83.79- \\
99.92\end{array}$ & 0.031 & 96.88 \\
\hline MUC-1 & 0.390 & 100 & $\begin{array}{l}54.07- \\
100\end{array}$ & 96.88 & $\begin{array}{l}83.79- \\
99.92\end{array}$ & 0.031 & 96.88 \\
\hline C-MYC & 0.389 & 100 & $\begin{array}{l}54.07- \\
100\end{array}$ & 100 & $\begin{array}{l}89.11- \\
100\end{array}$ & 0.0 & 100.0 \\
\hline \multicolumn{8}{|c|}{ No positive likelihood ratio $(\mathrm{LR}+)$ values because all specificity values were $100 \%$. } \\
\hline
\end{tabular}

The efficiency of studied markers in monitoring treatment response before, during, and after treatment was evaluated. Values of PCNA, P53, and MUC-1 significantly decreased after treatment of mammary tumor using PPTT alone (Table 5). At any marker reading, regardless treatment group, total tumors area in any given cat had no significant effect on the corresponding PCNA $\left(F_{1,58}=0.60, p=0.4407\right), \operatorname{P53}\left(F_{1,57}=0.07, p\right.$ $=0.7877)$, MUC-1 $\left(F_{1,61}=0.37, p=0.5468\right)$, and C-MYC $\left(F_{1,58}=0.25, p=0.6201\right)$ values. After controlling for total tumors area, there were no significant differences among treatments in all measured values of PCNA 
$\left(F_{2,28}=0.07, p=0.9362\right), \mathrm{P} 53\left(F_{2,22}=3.13, p=0.0632\right), \mathrm{MUC}-1(\mathrm{~F} 2,29=1.04, \mathrm{p}=0.3673)$, and C-MYC $\left(F_{2,23}=\right.$ $1.01, p=0.3790)$.

Table 5. Comparison between AAbs values measured before treatment (first) and after treatment (last). Significant results at $p<0.05$ if (bold).

\begin{tabular}{|c|c|c|c|c|c|c|c|}
\hline \multirow[t]{2}{*}{ Marker } & \multirow[t]{2}{*}{ Sample } & \multicolumn{2}{|l|}{ PPTT } & \multicolumn{2}{|c|}{ Surgery } & \multicolumn{2}{|c|}{ Surgery + PPTT } \\
\hline & & $\begin{array}{l}\text { Mean } \\
\pm S E\end{array}$ & $t_{(\mathrm{df})}, p$ & $\begin{array}{l}\text { Mean } \\
\pm S E\end{array}$ & $t_{(\mathrm{df})}, p$ & $\begin{array}{l}\text { Mean } \\
\pm S E\end{array}$ & $t_{(\mathrm{df})}, p$ \\
\hline \multirow[t]{2}{*}{ PCNA } & First & $\begin{array}{l}1.20 \pm \\
014\end{array}$ & \multirow[t]{2}{*}{$\begin{array}{l}t_{(14)}=4.29 \\
p=0.0078\end{array}$} & $\begin{array}{l}1.25 \pm \\
0.29\end{array}$ & \multirow[t]{2}{*}{$\begin{array}{l}t_{(14)}=0.49 p= \\
0.9959\end{array}$} & $\begin{array}{l}1.04 \pm \\
0.29\end{array}$ & \multirow[t]{2}{*}{$\begin{array}{l}t_{(14)}=0.71 \\
p=0.9776\end{array}$} \\
\hline & Last & $\begin{array}{l}0.79 \pm \\
0.11\end{array}$ & & $\begin{array}{l}1.17 \pm \\
0.21\end{array}$ & & $\begin{array}{l}0.95 \pm \\
0.26\end{array}$ & \\
\hline \multirow[t]{2}{*}{ P53 } & First & $\begin{array}{l}1.52 \pm \\
0.13\end{array}$ & \multirow[t]{2}{*}{$\begin{array}{l}t_{(14)}=4.98 p= \\
0.0022\end{array}$} & $\begin{array}{l}1.50 \pm \\
0.29\end{array}$ & \multirow[t]{2}{*}{$\begin{array}{l}t_{(14)}=0.85 p= \\
0.9522\end{array}$} & $\begin{array}{l}1.11 \pm \\
0.23\end{array}$ & \multirow[t]{2}{*}{$\begin{array}{l}t_{(14)}=0.31 p= \\
0.9995\end{array}$} \\
\hline & Last & $\begin{array}{l}1.06 \pm \\
0.14\end{array}$ & & $\begin{array}{l}1.36 \pm \\
0.25\end{array}$ & & $\begin{array}{l}1.07 \pm \\
0.20\end{array}$ & \\
\hline \multirow[t]{2}{*}{ MUC-1 } & First & $\begin{array}{l}1.59 \pm \\
0.15\end{array}$ & \multirow[t]{2}{*}{$\begin{array}{l}t_{(14)}=3.52 p= \\
0.0325\end{array}$} & $\begin{array}{l}1.89 \pm \\
0.33\end{array}$ & \multirow[t]{2}{*}{$\begin{array}{l}t_{(14)}=0.73 p= \\
0.9753\end{array}$} & $\begin{array}{l}1.48 \pm \\
0.26\end{array}$ & \multirow[t]{2}{*}{$\begin{array}{l}t_{(14)}=1.11 p= \\
0.8702\end{array}$} \\
\hline & Last & $\begin{array}{l}1.04 \pm \\
0.17\end{array}$ & & $\begin{array}{l}1.69 \pm \\
0.31\end{array}$ & & $\begin{array}{l}1.71 \pm \\
0.25\end{array}$ & \\
\hline \multirow[t]{2}{*}{ C-MYC } & First & $\begin{array}{l}0.92 \pm \\
0.07\end{array}$ & \multirow[t]{2}{*}{$\begin{array}{l}t_{(14)}=1.99 p= \\
0.3960\end{array}$} & $\begin{array}{l}1.22 \pm \\
0.25\end{array}$ & \multirow[t]{2}{*}{$\begin{array}{l}t_{(14)}=0.44 p= \\
0.9975\end{array}$} & $\begin{array}{l}0.98 \pm \\
0.16\end{array}$ & \multirow[t]{2}{*}{$\begin{array}{l}t_{(14)}=0.06 p= \\
0.9529\end{array}$} \\
\hline & Last & $\begin{array}{l}1.09 \pm \\
0.07\end{array}$ & & $\begin{array}{l}1.15 \pm \\
0.14\end{array}$ & & $\begin{array}{l}0.98 \pm \\
0.09\end{array}$ & \\
\hline
\end{tabular}

The overall prevalence rate (PR) of developing metastasis after starting the treatment course was $17.7 \%$. This PR was $0.0 \%$ in TS, $12.5 \%$ in TP, and $33.3 \%$ in TSP. The overall PR of the appearance of secondary tumor(s) after starting the course of treatment was $35.3 \%$. This PR was $0.0 \%$ in TS, $50.0 \%$ in TP, and $33.3 \%$ in TSP. The efficiency of studied markers in early diagnosis of secondary tumors and metastasis during the PPTT treatment course were evaluated (Table 6). Within a month before the clinical appearance of secondary tumors, there was an increase in C-MYC values. However, this increase was not statistically significant (Table 6). Also, the increases in "predictive" values of studied markers did not appear to be statistically significant (Table 6).

The overall PR of the appearance of the recurrent tumor(s) after starting the course of treatment was $35.3 \%$. This PR was $66.7 \%$ in TS, $25.0 \%$ in TP, and $33.3 \%$ in TSP. The efficiency of studied markers in the early diagnosis of recurrent tumors after starting the course of treatment were evaluated (Table 7). Although there were increases in some AAbs values within a month before the clinical appearance of recurrent tumors, however, the increases were not statistically significant (Table 7). 
The efficiency of studied markers in the early diagnosis of primary tumors was evaluated. Five apparently healthy $(H ; n=5)$ cats showed positive AAbs values of $1.11 \pm 0.10$ for PCNA, $1.08 \pm 0.12$ for P53, $1.15 \pm 0.10$ for MUC-1, and $1.04 \pm 0.07$ for C-MYC. By following two of them for 11 months, they did not show any clinical manifestation of mammary carcinoma. Therefore, we could not validate AAbs' efficiency in early diagnosis of feline mammary carcinoma as in human breast cancer.

In our study, across all treatments, the median survival time $\pm S E$ for cats without metastasis $(530.0 \pm 162.79$ d; $n=11 ; 64 \%$ censored) was significantly higher (Figure 1 ; Log-rank test: $\chi_{(1)}^{2}=8.38, p=0.004$ ) than that for cats with metastasis $(112.0 \pm 66.14 \mathrm{~d} ; n=6 ; 17 \%$ censored). While the median survival times $\pm S E$ for TS ( $90.0 \pm 12.25 \mathrm{~d} ; n=3 ; 33 \%$ censored), TSP (307 $\pm 213.61 \mathrm{~d} ; n=5 ; 20.0 \%$ censored), and TP (530 $\pm 0.0 \mathrm{~d} ; n=$ 9; $67 \%$ censored) were not significantly different (Figure 2 ; Log-rank test: $\chi^{2}{ }_{(2)}=3.13, p=0.209$ ).

Table 6. Comparison between AAbs values measured just before the appearance of secondary tumors and metastasis (predictive), and last values measured before the predictive values (pre-predictive). The overall values were calculated regardless of treatments. Significant results at $p<0.05$ if (bold). 


\begin{tabular}{|c|c|c|c|c|c|c|c|c|c|c|}
\hline \multirow[t]{2}{*}{ Event } & \multirow[t]{2}{*}{ Marker } & \multirow[t]{2}{*}{$\begin{array}{l}\text { Sampling } \\
\text { time }\end{array}$} & \multicolumn{3}{|c|}{ Overall } & \multicolumn{3}{|c|}{ PPTT } & \multicolumn{2}{|c|}{$\begin{array}{l}\text { Surgery + PPTT } \\
(n=2)\end{array}$} \\
\hline & & & $n$ & $\begin{array}{l}\text { Mean } \\
\pm S E\end{array}$ & $F_{\mathrm{df}}, p$ & $n$ & $\begin{array}{l}\text { Mean } \\
\pm S E\end{array}$ & $t_{(\mathrm{df})}, p$ & $\begin{array}{l}\text { Mean } \\
\pm S E\end{array}$ & $t_{(\mathrm{df})}, p$ \\
\hline \multirow[t]{8}{*}{$\begin{array}{l}\text { Secondary } \\
\text { tumor }\end{array}$} & \multirow[t]{2}{*}{ PCNA } & $\begin{array}{l}\text { Pre- } \\
\text { predictive }\end{array}$ & 10 & $\begin{array}{l}1.16 \\
\pm \\
0.13\end{array}$ & \multirow{2}{*}{$\begin{array}{l}F_{1,11}= \\
1.01 \\
p= \\
0.3338\end{array}$} & 8 & $\begin{array}{l}1.18 \\
\pm \\
0.11\end{array}$ & \multirow{2}{*}{$\begin{array}{l}t_{(12)}= \\
0.33 \\
p= \\
0.9864\end{array}$} & $\begin{array}{l}1.08 \\
\pm \\
0.60\end{array}$ & \multirow{2}{*}{$\begin{array}{l}t_{(11)}= \\
1.28 \\
p= \\
0.5927\end{array}$} \\
\hline & & Predictive & 12 & $\begin{array}{l}1.16 \\
\pm \\
0.13\end{array}$ & & 10 & $\begin{array}{l}1.13 \\
\pm \\
0.10\end{array}$ & & $\begin{array}{l}1.29 \\
\pm \\
0.73\end{array}$ & \\
\hline & \multirow[t]{2}{*}{ P53 } & $\begin{array}{l}\text { Pre- } \\
\text { predictive }\end{array}$ & 10 & $\begin{array}{l}1.26 \\
\pm \\
0.13\end{array}$ & \multirow{2}{*}{$\begin{array}{l}F_{1,11}= \\
0.11 \\
p= \\
0.7420\end{array}$} & 8 & $\begin{array}{l}1.38 \\
\pm \\
0.12\end{array}$ & \multirow{2}{*}{$\begin{array}{l}t_{(12)}= \\
0.14 \\
p= \\
0.9990\end{array}$} & $\begin{array}{l}0.78 \\
\pm \\
0.09\end{array}$ & \multirow{2}{*}{$\begin{array}{l}t_{(11)}= \\
0.31 \\
p= \\
0.9894\end{array}$} \\
\hline & & Predictive & 12 & $\begin{array}{l}1.24 \\
\pm \\
0.12\end{array}$ & & 10 & $\begin{array}{l}1.34 \\
\pm \\
0.12\end{array}$ & & $\begin{array}{l}0.73 \\
\pm \\
0.11\end{array}$ & \\
\hline & \multirow[t]{2}{*}{ MUC-1 } & $\begin{array}{l}\text { Pre- } \\
\text { predictive }\end{array}$ & 10 & $\begin{array}{l}1.52 \\
\pm \\
0.12\end{array}$ & \multirow{2}{*}{$\begin{array}{l}F_{1,11}= \\
0.07 \\
p= \\
0.7903\end{array}$} & 8 & $\begin{array}{l}1.53 \\
\pm \\
0.07\end{array}$ & \multirow{2}{*}{$\begin{array}{l}t_{(12)}= \\
0.01 \\
p= \\
0.9908\end{array}$} & $\begin{array}{l}1.52 \\
\pm \\
0.72\end{array}$ & \multirow{2}{*}{$\begin{array}{l}t_{(11)}= \\
0.31 \\
p= \\
0.9892\end{array}$} \\
\hline & & Predictive & 12 & $\begin{array}{l}1.48 \\
\pm \\
0.12\end{array}$ & & 10 & $\begin{array}{l}1.48 \\
\pm \\
0.11\end{array}$ & & $\begin{array}{l}1.46 \\
\pm \\
0.61\end{array}$ & \\
\hline & \multirow[t]{2}{*}{ C-MYC } & $\begin{array}{l}\text { Pre- } \\
\text { predictive }\end{array}$ & 10 & $\begin{array}{l}0.86 \\
\pm \\
0.05\end{array}$ & \multirow{2}{*}{$\begin{array}{l}F_{1,8}= \\
1.11 \\
p= \\
0.3225\end{array}$} & 8 & $\begin{array}{l}0.85 \\
\pm \\
0.06\end{array}$ & \multirow{2}{*}{$\begin{array}{l}t_{(8)}= \\
0.87 \\
p= \\
0.8196\end{array}$} & $\begin{array}{l}0.91 \\
\pm \\
0.05\end{array}$ & \multirow{2}{*}{$\begin{array}{l}t_{(7)}= \\
0.74 \\
p= \\
0.8775\end{array}$} \\
\hline & & Predictive & 12 & $\begin{array}{l}0.90 \\
\pm \\
0.06\end{array}$ & & 10 & $\begin{array}{l}0.89 \\
\pm \\
0.07\end{array}$ & & $\begin{array}{l}0.98 \\
\pm \\
0.05\end{array}$ & \\
\hline \multirow[t]{4}{*}{ Metastasis } & \multirow[t]{2}{*}{ PCNA } & $\begin{array}{l}\text { Pre- } \\
\text { predictive }\end{array}$ & 5 & $\begin{array}{l}1.20 \\
\pm \\
0.24\end{array}$ & \multirow{2}{*}{$\begin{array}{l}F_{1,6}= \\
0.04 \\
p= \\
0.8540\end{array}$} & 3 & $\begin{array}{l}1.29 \\
\pm \\
0.23\end{array}$ & \multirow{2}{*}{$\begin{array}{l}t_{(6)}= \\
0.09 \\
p= \\
0.9997\end{array}$} & $\begin{array}{l}1.08 \\
\pm \\
0.60\end{array}$ & \multirow{2}{*}{$\begin{array}{l}t_{(6)}= \\
0.32 \\
p= \\
0.9873\end{array}$} \\
\hline & & Predictive & 5 & $\begin{array}{l}1.26 \\
\pm \\
0.28\end{array}$ & & 3 & $\begin{array}{l}1.24 \\
\pm \\
0.30\end{array}$ & & $\begin{array}{l}1.29 \\
\pm \\
0.73\end{array}$ & \\
\hline & \multirow[t]{2}{*}{ P53 } & $\begin{array}{l}\text { Pre- } \\
\text { predictive }\end{array}$ & 5 & $\begin{array}{l}1.12 \\
\pm \\
0.18\end{array}$ & \multirow{2}{*}{$\begin{array}{l}F_{1,6}= \\
0.21 \\
p= \\
0.6628\end{array}$} & 3 & $\begin{array}{l}1.34 \\
\pm \\
0.20\end{array}$ & \multirow{2}{*}{$\begin{array}{l}t_{(6)}= \\
0.89 \\
p= \\
0.8111\end{array}$} & $\begin{array}{l}0.78 \\
\pm \\
0.09\end{array}$ & \multirow{2}{*}{$\begin{array}{l}t_{(6)}= \\
0.13 \\
p= \\
0.9990\end{array}$} \\
\hline & & Predictive & 5 & $\begin{array}{l}1.26 \\
\pm\end{array}$ & & 3 & $\begin{array}{l}1.61 \\
\pm\end{array}$ & & $\begin{array}{l}0.73 \\
\pm\end{array}$ & \\
\hline
\end{tabular}




\begin{tabular}{|c|c|c|c|c|c|c|c|c|c|}
\hline \multirow[t]{2}{*}{ MUC-1 } & $\begin{array}{l}\text { Pre- } \\
\text { predictive }\end{array}$ & 5 & $\begin{array}{l}1.60 \\
\pm \\
0.31\end{array}$ & \multirow{2}{*}{$\begin{array}{l}F_{1,6}= \\
0.01 \\
p= \\
0.9913\end{array}$} & 3 & $\begin{array}{l}1.66 \\
\pm \\
0.37\end{array}$ & \multirow{2}{*}{$\begin{array}{l}t_{(6)}= \\
0.07 \\
p= \\
0.9998\end{array}$} & $\begin{array}{l}1.52 \\
\pm \\
0.72\end{array}$ & \multirow{2}{*}{$\begin{array}{l}t_{(6)}= \\
0.07 \\
p= \\
0.9998\end{array}$} \\
\hline & Predictive & 5 & $\begin{array}{l}1.61 \\
\pm \\
0.32\end{array}$ & & 3 & $\begin{array}{l}1.71 \\
\pm \\
0.44\end{array}$ & & $\begin{array}{l}1.46 \\
\pm \\
0.61\end{array}$ & \\
\hline
\end{tabular}

\begin{tabular}{|c|c|c|c|c|c|c|c|c|c|}
\hline \multirow[t]{2}{*}{ C-MYC } & $\begin{array}{l}\text { Pre- } \\
\text { predictive }\end{array}$ & 5 & $\begin{array}{l}0.87 \\
\pm \\
0.06\end{array}$ & \multirow{2}{*}{$\begin{array}{l}F_{1,6}= \\
3.12 \\
p= \\
0.1278\end{array}$} & 3 & $\begin{array}{l}0.84 \\
\pm \\
0.11\end{array}$ & \multirow{2}{*}{$\begin{array}{l}t_{(6)}= \\
2.08 \\
p= \\
0.2596\end{array}$} & $\begin{array}{l}0.91 \\
\pm \\
0.05\end{array}$ & \multirow{2}{*}{$\begin{array}{l}t_{(6)}= \\
0.58 \\
p= \\
0.9340\end{array}$} \\
\hline & Predictive & 5 & $\begin{array}{l}1.02 \\
\pm \\
0.04\end{array}$ & & 3 & $\begin{array}{l}1.05 \\
\pm \\
0.05\end{array}$ & & $\begin{array}{l}0.98 \\
\pm \\
0.05\end{array}$ & \\
\hline
\end{tabular}

Table 7. Comparison between AAbs values measured just before the appearance of recurrent tumors (predictive), and last values measured before the predictive values (pre-predictive). The overall values were calculated regardless of treatments. Significant results at $p<0.05$ if (bold).

\begin{tabular}{|c|c|c|c|c|c|c|c|c|c|}
\hline \multirow[t]{2}{*}{ Marker } & \multirow[t]{2}{*}{$\begin{array}{l}\text { Sampling } \\
\text { time }\end{array}$} & \multicolumn{2}{|l|}{$\begin{array}{l}\text { Overall } \\
(n=6)\end{array}$} & \multicolumn{2}{|l|}{$\begin{array}{l}\text { Surgery } \\
(n=2)\end{array}$} & \multicolumn{2}{|l|}{$\begin{array}{l}\text { PPTT } \\
(n=3)\end{array}$} & \multicolumn{2}{|c|}{$\begin{array}{l}\text { Surgery + PPTT } \\
(n=1)\end{array}$} \\
\hline & & $\begin{array}{l}\text { Mean } \\
\pm S E\end{array}$ & $F_{\mathrm{df}}, p$ & $\begin{array}{l}\text { Mean } \\
\pm S E\end{array}$ & $t_{(\mathrm{df})}, p$ & $\begin{array}{l}\text { Mean } \\
\pm S E\end{array}$ & $t_{(\mathrm{df})}, p$ & $\begin{array}{l}\text { Mean } \\
\pm S E\end{array}$ & $t_{(\mathrm{df})}, p$ \\
\hline \multirow[t]{2}{*}{ PCNA } & $\begin{array}{l}\text { Pre- } \\
\text { predictive }\end{array}$ & $\begin{array}{l}1.23 \pm \\
0.18\end{array}$ & \multirow{2}{*}{$\begin{array}{l}F_{1,3}= \\
2.40 \\
p= \\
0.2192\end{array}$} & $\begin{array}{l}0.81 \pm \\
0.24\end{array}$ & \multirow{2}{*}{$\begin{array}{l}t_{(3)}= \\
3.23 \\
p= \\
0.1777\end{array}$} & $\begin{array}{l}1.36 \pm \\
0.18\end{array}$ & \multirow{2}{*}{$\begin{array}{l}t_{(3)}= \\
2.70 \\
p= \\
0.2703\end{array}$} & $\begin{array}{l}1.68 \pm \\
0.0\end{array}$ & \multirow{2}{*}{$\begin{array}{l}t_{(3)}= \\
1.37 \\
p= \\
0.7437\end{array}$} \\
\hline & Predictive & $\begin{array}{l}1.28 \pm \\
0.22\end{array}$ & & $\begin{array}{l}1.37 \pm \\
0.03\end{array}$ & & $\begin{array}{l}0.97 \pm \\
0.31\end{array}$ & & $\begin{array}{l}2.02 \pm \\
0.0\end{array}$ & \\
\hline \multirow[t]{2}{*}{ P53 } & $\begin{array}{l}\text { Pre- } \\
\text { predictive }\end{array}$ & $\begin{array}{l}1.01 \pm \\
0.09\end{array}$ & \multirow{2}{*}{$\begin{array}{l}F_{1,3}= \\
0.41 \\
p= \\
0.5687\end{array}$} & $\begin{array}{l}1.05 \pm \\
0.06\end{array}$ & \multirow{2}{*}{$\begin{array}{l}t_{(3)}= \\
1.1 \\
p= \\
0.8537\end{array}$} & $\begin{array}{l}1.09 \pm \\
0.13\end{array}$ & \multirow{2}{*}{$\begin{array}{l}t_{(3)}= \\
0.35 \\
p= \\
0.9986\end{array}$} & $\begin{array}{l}0.69 \pm \\
0.0\end{array}$ & \multirow{2}{*}{$\begin{array}{l}t_{(3)}= \\
0.13 \\
p= \\
0.9069\end{array}$} \\
\hline & Predictive & $\begin{array}{l}1.21 \pm \\
0.23\end{array}$ & & $\begin{array}{l}1.51 \pm \\
0.34\end{array}$ & & $\begin{array}{l}1.21 \pm \\
0.36\end{array}$ & & $\begin{array}{l}0.61 \pm \\
0.0\end{array}$ & \\
\hline \multirow[t]{2}{*}{ MUC-1 } & $\begin{array}{l}\text { Pre- } \\
\text { predictive }\end{array}$ & $\begin{array}{l}1.74 \pm \\
0.14\end{array}$ & \multirow{2}{*}{$\begin{array}{l}F_{1,3}= \\
0.08 \\
p= \\
0.7905\end{array}$} & $\begin{array}{l}1.53 \pm \\
0.02\end{array}$ & \multirow{2}{*}{$\begin{array}{l}t_{(3)}= \\
1.28 \\
p= \\
0.7848\end{array}$} & $\begin{array}{l}1.72 \pm \\
0.21\end{array}$ & \multirow{2}{*}{$\begin{array}{l}t_{(3)}= \\
1.65 \\
p= \\
0.6199\end{array}$} & $\begin{array}{l}2.24 \pm \\
0.0\end{array}$ & \multirow{2}{*}{$\begin{array}{l}t_{(3)}= \\
0.35 \\
p= \\
0.9987\end{array}$} \\
\hline & Predictive & $\begin{array}{l}1.63 \pm \\
0.29\end{array}$ & & $\begin{array}{l}1.98 \pm \\
0.02\end{array}$ & & $\begin{array}{l}1.25 \pm \\
0.50\end{array}$ & & $\begin{array}{l}2.07 \pm \\
0.0\end{array}$ & \\
\hline \multirow[t]{2}{*}{ C-MYC } & $\begin{array}{l}\text { Pre- } \\
\text { predictive }\end{array}$ & $\begin{array}{l}0.96 \pm \\
0.04\end{array}$ & \multirow{2}{*}{$\begin{array}{l}F_{1,3}= \\
4.66 \\
p= \\
0.1198\end{array}$} & $\begin{array}{l}0.99 \pm \\
0.05\end{array}$ & \multirow{2}{*}{$\begin{array}{l}t_{(3)}= \\
2.33 \\
p= \\
0.3638\end{array}$} & $\begin{array}{l}0.94 \pm \\
0.07\end{array}$ & \multirow{2}{*}{$\begin{array}{l}t_{(3)}= \\
2.44 \\
p= \\
0.3317\end{array}$} & $\begin{array}{l}0.96 \pm \\
0.0\end{array}$ & \multirow{2}{*}{$\begin{array}{l}t_{(3)}= \\
0.14 \\
p= \\
0.8989\end{array}$} \\
\hline & Predictive & $\begin{array}{l}1.17 \pm \\
0.06\end{array}$ & & $\begin{array}{l}1.27 \pm \\
0.14\end{array}$ & & $\begin{array}{l}1.18 \pm \\
0.03\end{array}$ & & $\begin{array}{l}0.93 \pm \\
0.0\end{array}$ & \\
\hline
\end{tabular}


Among several technologies, ELISA has been applied for the detection of AAbs in the serum of breast cancer (BC) patients [40]. The cornerstone in improving ELISA accuracy of AAbs detection is tailoring a panel of highly sensitive and specific TAAs. Because single TAAs application in diagnosis of BC demonstrated that only $10-30 \%$ of cancer patients elicited specific AAbs. The reason for this low sensitivity could lie in the heterogeneous nature of $\mathrm{BC}$, whereby different proteins are aberrantly processed or regulated in patients with the same type of cancer [41]. Until now no confirmed model of TAAs for detection of AAbs performed with a sensitivity that would be acceptable for use in screening of $B C$ [42]. In the present investigation, we tailored a panel of four TAAs, three of them (P53, MUC-1, and C-MYC) are the top among all BC associated tumor antigens used for detection of autoantibodies in terms of the frequency studies in addition to their close structural and function in BC. While the fourth TAAs (PCNA), it is the first time to study the relationship between its AAbs and mammary tumors concerning that PCNA TAAs were detected in sera of diseased animals with various types of cancers such as duodenal, breast and in non-small lung cancers and considered as an important prognostic indicator of cancer. Authors added that PCNA TAA high levels of expression were closely related to the occurrence, development, and prognosis of $\mathrm{BC}$ [43]. Although the detection of the autoantibodies accepted a raise of interest as a tool for diagnosis, early diagnosis, and monitoring of treatment response of different therapeutic modalities in cancers including breast cancer, PCNA autoantibodies have been seldom reported. In the present article, detection of PCNA AAbs in cats with mammary gland carcinoma revealed $93.75 \%$ sensitivity and $100 \%$ specificity confirmed the conclusions provided by Malkas. et al. (2006) [44] about the usefulness of PCNA antibodies as a marker of BC and that these antibodies could serve as a highly effective detector of malignancy. As shown in Figure (3), all 34 cats revealed positive ELISA for C-MYC, 33 cats were positive for MUC-1, and 32 cats were positive for PCNA and P53. While the negative control animal cut-off values for PCNA, P53, MUC-1, and C-MYC were 0.314, 0.351, 0.39 , and 0.389, respectively as showed in Table (4). The results in Figure (4) and Table (4) indicated the high specificity and sensitivity of each TAA in our panel for detection of AAbs using ELISA, however, a single TAA cannot be used alone as the single TAA can detect AAbs in other noncancerous diseases [45]. Five of the 11 apparently normal cats showed positive levels of AAbs. These positive AAbs permit the suggestion that they were asymptomatically diseased animals (negative for clinical manifestation), but they are in the early stage of tumorigenesis and they are at the risk of mammary tumor appearance [8]. If so, our panel of TAA can be recommended for early diagnosis of $B C$, but this suggestion will be confirmed after a follow-up of these five cats until the appearance of primary mammary tumors as we follow them clinically for only 11 months. In women breast cancer, AAbs could be detected in sera of patients between seven and twentyseven months before the cancer was diagnosed on the screening mammograms, and in a large cohort, AAbs could be detected up to four years before mammographic detection [46]. In the group treated with PPTT monotherapy, the AAbs panel values were non-significantly decreased during different cycles of PPTT. While the AAbs panel values after the end of treatment (after three months) were significantly decreased than the first values before initiation of PPTT therapy. We can indicate that the high level of AAbs before the treatment with PPTT was correlated with tumor burden. After three months of the end of treatment, there was a significant decrease in AAbs level associated with a large reduction or complete disappearance of the tumor mass which mean a decrease of the TAAs and this in the hand of Evans. et al, 2018 [47] who demonstrated that reduction of large tumor mass was associated with eradication of TAAs hence the immune system would be exposed to fewer cancer antigens reducing the level of AAbs. The group treated

Page 14/27 
with PPTT monotherapy included two cases that were diagnosed with lung metastasis. One of them showed a significant decrease in AAbs values after three months from the end of local treatment of the mammary carcinoma with PPTT monotherapy and exhibited progression-free survival (PFS) and overall survival (OS) similar to whole group cases. We can explain this by the abscopal phenomenon described before by Yilmaz. et al. (2019) [48] as a systemic anti-tumor immune response that reflects the regression of non-irradiated metastatic lesions at a distance from the primary site of irradiation which means a decrease tumor burden all over the body not only the local treated site. Although there was a significant decrease in the AAbs panel values after the end of the treatment, these values did not reach values lower than the cut-off value (do not convert to normal value) which indicated AAbs persist in serum for long period. This data agrees with Suppiah and Greenman. (2013)[49] who mentioned that patients whose serum are positive for P53 AAbs at diagnosis do not convert to negative even after the cancer is completely excised. It seems that once the patient's immune system has been primed, there is sufficient P53 antigen available to maintain a long-term anti-p53 humoral response. Depending on this data, we can suggest that any elevation of our AAbs panel values post decrease means the appearance of TAAs subsequent early tumorigenesis process before the appearance of clinical manifestation and paved us to suggest that this elevation can be used as an early prediction for secondary tumor, recurrence, or metastasis (Figure 5).

Also, in the group treated with PPTT monotherapy during the treatment course, there is a non-significance increase in AAbs level within a month before clinical appearance of secondary tumors, recurrence, or metastasis which agrees with Zalcman. et al. (1998) [50] who mentioned that any temporal changes in the level of P53-AAbs could be closely correlated with disease progression or regression in colon cancer. The reappearance of such antibodies may indicate a relapse of the disease. In the groups treated with surgery only or a combination between PPTT and surgery, there was no significant difference in AAbs panel values before and after the treatment with one month and a half (it is the available follow-up period). The persistence of AAbs after only one month and a half post-surgery confirmed that AAbs persist high for three months after the end of PPTT therapy. So, we can lay the non-significant changes in AAbs values in the second and third groups on the short follow-up period which must be more than three months after the end of treatment. These data in the hand of Takeda. et al, (2001) [51] who reported that AAbs persisted in the serum of colorectal cancer patients for at least six months after surgical removal of cancer. This persistence of AAbs for three months after the end of PPTT therapy and after six months of surgical removal of cancer may be attributed to the long-lived population of memory plasma cells that can survive for months or years in circulation in a quiescent state [52]. The long overall survival of cats treated with PPTT monotherapy can be explained, as reported before [53], by the abscopal effect of radiation therapy that does not only exert direct cytotoxic effects on tumor cells but also initiates immunogenic cell death causing production and release of the cytokines and chemokines into the tumor microenvironment. This causes chemoattraction and infiltration of dendritic cells (Dcs) to the site of the tumor. Activation of Dcs, which are essential antigenpresenting cells, up-regulation of cytotoxic $T$ lymphocytes, induce a systemic antitumor response outside the irradiation field, and finally significantly delayed tumor growth and prolonged median survival time. But this abscopal effect caused by radiation monotherapy is quite rare and has not been extensively investigated.

\section{Conclusion}


Our panel of TAAs tailored from PCNA, P53, MUC-1, and C-MYC showed high specificity and sensitivity for the diagnosis of feline mammary tumors. Our panel also was valid for monitoring of treatment response of plasmonic photothermal therapy (PPTT) with three months after the end of the treatment. We suggest monitoring of AAbs level in cats with mammary tumors treated with surgery only or treated with a combination of surgery and PPTT for a longer period at least three months from the date of surgery to evaluate the difference in treatment response between them. We cannot confirm the validity of our panel in early diagnosis (prediction) of primary feline primary mammary tumors. Thus, we recommend a long followup period of positive normal cats (without clinical manifestation) more than 11 months with a larger population sample as reported in human breast cancer. Our panel was not valid in early detection of secondary tumor or metastasis during the treatment course of PPTT but our suggestion of their validity for early diagnosis of recurrence, secondary tumor, or metastasis is conditioned after the end of treatment (significant decrease in the AAbs) which need a long period of follow-up with large sample population to be proven. The assessment of AAbs values at any subsequent follow-up time points accurately and reproducibly predicts the clinical outcome. The survival time among treatments was higher in the PPTT monotherapy group than the surgery only group or group of combination between them.

\section{Abbreviations}

PPTT: plasmonic photothermal therapy

TAAs: tumor-associated antigens

AAbs: autoantibodies

PCNA: proliferating cell nuclear antigen

ROC: receiver operating characteristic

OS: overall survival

PFS: progression-free survival

DCs: dendritic cells

\section{Declarations}

Ethics approval: the Institutional Animal Care and Use Committee (CU-IACUC) Cairo University (code: CU II F 9 16).

Consent of publication: not applicable.

Availability of data and materials: the datasets used or analyzed during the current study available from the corresponding authors on reasonable request.

Competing interests: The authors declare that they have no competing interest. 
Funding: This research was funded by the joint collaborative Efforts of the Egyptian Expatriates and Scientific Organization toward Tackling National R\&D challenges (JESOR).

Authors' contributions: A. S conceived and designed the study. A. M. R, H. A. M. F, and I. A. E collected the data. H. A. M. F and I. A. E diagnosed, performed the surgical interventions (mastectomy), and applied PPTT of mammary carcinoma feline cases. A. M. R, M. G, S. A, and M. A. G performed Enzyme-Linked Immunosorbent Assay (ELISA), data analysis, and interpretation. H. A. A performed the statistical analysis. S. A. S, H. A. M. F, H. A. A, and A. M. R wrote the paper. All authors revised and approved the final manuscript.

Acknowledgments: We thank Prof. Mostafa A. El-Sayed (Julius Brown Chair and Regents Professor Director, Laser Dynamics Lab, School of Chemistry and Biochemistry, Georgia Institute of Technology, Atlanta, GA, USA, E-mail: melsayed@gatech.edu) for providing the Gold nanorods (AuNRs) and the diode laser used in the present work. We also thank JESOR program of the Egyptian Academy for Scientific Researches and Technology (Address: 101 Kasr Al-Ainist, Cairo, Egypt, Postal Code: 11516, E-mail: ASRT@ASRT.SCI.EG) for the great support of this work.

\section{References}

[1] Adega F, Borges A, Chaves R. Cat mammary tumors: Genetic models for the human counterpart. Vet Sci 2016; 3(3). https://doi.org/10.3390/vetsci3030017.

[2] Edechi C, Ikeogu N, Uzonna J, Myal Y. Regulation of Immunity in Breast Cancer. Cancers (Basel) 2019; 11(8):1080. https://doi.org/10.3390/cancers11081080.

[3] Anderson KS, LaBaer J. The sentinel within: exploiting the immune system for cancer biomarkers. J Proteome Res 2005; 4(4):1123-33. https://doi.org/10.1021/pr0500814.

[4] Kabel AM. Tumor markers of breast cancer: New prospectives. J Oncol Sci 2017; 3(1):5-11. https://doi.org/10.1016/j.jons.2017.01.001.

[5] Zaenker P, Gray ES, Ziman MR. Autoantibody Production in Cancer-The Humoral Immune Response toward Autologous Antigens in Cancer Patients. Autoimmun Rev 2016; 15:477-83. https://doi.org/10.1016/j.autrev.2016.01.017.

[6] Chapman CJ, Murray A, McElveen JE, Sahin U, Luxemburger U, Türeci O, et al. Autoantibodies in lung cancer: possibilities for early detection and subsequent cure. Thorax 2008; 63(3):228-33. https://doi.org/10.1136/thx.2007.083592.

[7] Xia J, Shi J, Wang P, Song C, Wang K, Zhang J, et al. Tumour-Associated Autoantibodies as Diagnostic Biomarkers for Breast Cancer: A Systematic Review and Meta-Analysis. Scand J Immunol 2016; 83(6):393408. https://doi.org/10.1111/sji.12430.

[8] Qiu J, Keyser B, Lin ZT, Wu T. Autoantibodies as potential biomarkers in breast cancer. Biosensors 2018; 8(3):67. https://doi.org/10.3390/bios8030067. 
[9] Banin Hirata BK, Oda JMM, Losi Guembarovski R, Ariza CB, Oliveira CEC De, Watanabe MAE. Molecular markers for breast cancer: Prediction on tumor behavior. Dis Markers 2014.

https://doi.org/10.1155/2014/513158.

[10] Gendler SJ. MUC1, The renaissance molecule. J Mammary Gland Biol Neoplasia 2001; 6(3):339-53. https://doi.org/10.1023/A:1011379725811.

[11] Tansey WP. Mammalian MYC Proteins and Cancer. New J Sci 2014; 2014:1-27. https://doi.org/10.1155/2014/757534.

[12] Green AR, Aleskandarany MA, Agarwal D, Elsheikh S, Nolan CC, Diez-Rodriguez M, et al. MYC functions are specific in biological subtypes of breast cancer and confers resistance to endocrine therapy in luminal tumours. Br J Cancer 2016; 114(8):917-28. https://doi.org/10.1038/bjc.2016.46.

[13] ELSTON CW, ELLIS IO. Pathological prognostic factors in breast cancer. I. The value of histological grade in breast cancer: experience from a large study with long-term follow-up. Histopathology 1991; 19(5):403-10. https://doi.org/10.1111/j.1365-2559.1991.tb00229.x.

[14] Ali MRK, Ibrahim IM, Ali HR, Selim SA, El-Sayed MA. Treatment of natural mammary gland tumors in canines and felines using gold nanorods-assisted plasmonic photothermal therapy to induce tumor apoptosis. Int J Nanomedicine 2016; 11:4849-63. https://doi.org/10.2147/IJN.S109470.

[15] Ali MR, Farghali HA, Ali HR, Osman AH, Soliman YA, Wu Y, et al. Abstract 175: Combination of plasmonic photothermal therapy with surgery applied to naturally occurring mammary tumors in canines and felines: clinical outcomes and molecular studies. Cancer Res., vol. 77, American Association for Cancer Research (AACR); 2017, p. 175-175. https://doi.org/10.1158/1538-7445.am2017-175.

[16] Edechi C, Ikeogu N, Uzonna J, Myal Y. Regulation of Immunity in Breast Cancer. Cancers (Basel) 2019; 11(8):1080. https://doi.org/10.3390/cancers11081080.

[17] Liu Y, Liao Y, Xiang L, Jiang K, Li S, Huangfu M. A panel of autoantibodies as potential early diagnostic serum biomarkers in patients with breast cancer. Int J Clin Oncol 2016; 22(2):291-296. https://doi.org/10.1007/s10147-016-1047-0.

[18] Ali MRK, Farghali HAM, Wu Y, El-Sayed I, Osman AH, Selim SA, et al. Gold Nanorod-Assisted Photothermal Therapy Decreases Bleeding during Breast Cancer Surgery in Dogs and Cats. Cancers (Basel) 2019; 11(6):851. https://doi.org/10.3390/cancers11060851.

[19] Farghali HA, AbdElKader NA, Khattab MS, AbuBakr HO. Novel approach to gastric mucosal defect repair using fresh amniotic membrane allograft in dogs (experimental study). Stem Cell Res Ther 2017; 8(1):235. https://doi.org/10.1186/s13287-017-0682-3.

[20] Tankaew P, Singh-La T, Titaram C, Punyapornwittaya V, Vongchan P, Sawada T, et al. Evaluation of an Inhouse indirect ELISA for detection of antibody against haemorrhagic septicemia in Asian elephants. J Microbiol Methods 2017; 134:30-34. https://doi.org/10.1016/j.mimet.2017.01.008. 
[21] Tankaew P, Srisawat W, Singhla T, Tragoolpua K, Kataoka Y, Sawada T, et al. Comparison of two indirect ELISA coating antigens for the detection of dairy cow antibodies against Pasteurella multocida. J Microbiol Methods 2018; 145:20-7. https://doi.org/10.1016/j.mimet.2017.12.005.

[22] Poolperm P, Varinrak T, Kataoka Y, Tragoolpua K, Sawada T, Sthitmatee N. Development and standardization of an in-house indirect ELISA for detection of duck antibody to fowl cholera. J Microbiol Methods 2017; 142:10-14. https://doi.org/10.1016/j.mimet.2017.08.018.

[23] Näslund K, Blomqvist G, Vernersson C, Zientara S, Bréard E, Valarcher JF. Development and evaluation of an indirect enzyme-linked immunosorbent assay for serological detection of Schmallenberg virus antibodies in ruminants using whole virus antigen. Acta Vet Scand 2014; 56:71. https://doi.org/10.1186/s13028-0140071-1.

[24] https://www.ncbi.nlm.nih.gov/protein/P41685.1

[25] https://www.ncbi.nlm.nih.gov/protein/XP_023103255.1

[26] https://www.ncbi.nlm.nih.gov/protein/P68271.1

[27] https://www.ncbi.nlm.nih.gov/protein/XP_003983789.1

[28] Wang P, Qin J, Ye H, Li L, Wang X, Zhang J. Using a panel of multiple tumor-associated antigens to enhance the autoantibody detection in the immunodiagnosis of ovarian cancer. J Cell Biochem 2019; 120(3):3091-3100. https://doi.org/10.1002/jcb.27497.

[29] Jin Y, Kim SC, Kim HJ, Ju W, Kim YH, Kim HJ. Use of autoantibodies against tumor-associated antigens as serum biomarkers for primary screening of cervical cancer. Oncotarget 2017; 8(62):105425-105439. https://doi.org/10.18632/oncotarget.22231.

[30] Liu W, De La Torre IG, Gutiérrez-Rivera MC, Wang B, Liu Y, Dai L, et al. Detection of autoantibodies to multiple tumor-associated antigens (TAAs) in the immunodiagnosis of breast cancer. Tumor Biol 2015; 36(2):1307-12. https://doi.org/10.1007/s13277-014-2756-5.

[31] Ye H, Sun C, Ren P, Dai L, Peng B, Wang K, et al. Mini-array of multiple tumor-associated antigens (TAAs) in the immunodiagnosis of breast cancer. Oncol Lett 2013; 5:663-8. https://doi.org/10.3892/ol.2012.1062.

[32] Lu H, Ladd J, Feng Z, Wu M, Goodell V, Pitteri SJ, et al. Evaluation of known oncoantibodies, HER2, p53, and cyclin B1, in prediagnostic breast cancer sera. Cancer Prev Res 2012; 5(8):1036-1043. https://doi.org/10.1158/1940-6207.CAPR-11-0558.

[33] Hsu T-C, Tsay GJ, Chen T-Y, Liu Y-C, Tzang B-S. Anti-PCNA autoantibodies preferentially recognize Cterminal of PCNA in patients with chronic hepatitis B virus infection. Clin Exp Immunol 2006; 144(1):110116. https://doi.org/10.1111/j.1365-2249.2006.03046.x. 
[34] Zhang J, Casiano C, Peng X, Koziol J, Chan E, Tan E. Enhancement of antibody detection in cancer using panel of recombinant tumor-associated antigens. Cancer Epidemiol Biomarkers Prev 2003; 12(2):136-43.

[35] Takasaki Y, Kogure T, Takeuchi K, Kaneda K, Yano T, Hirokawa K, et al. Reactivity of Anti-Proliferating Cell Nuclear Antigen (PCNA) Murine Monoclonal Antibodies and Human Autoantibodies to the PCNA Multiprotein Complexes Involved in Cell Proliferation. J Immunol 2001; 166(7):4780-4787. https://doi.org/10.4049/jimmunol.166.7.4780.

[36] Tzang BS, Chen TY, Hsu TC, Liu YC, Tsay GJ. Presentation of autoantibody to proliferating cell nuclear antigen in patients with chronic hepatitis B and C virus infection. Ann Rheum Dis 1999; 58(10):630-634. https://doi.org/10.1136/ard.58.10.630.

[37] Crowther JR. ELISA. Theory and practice. Methods Mol Biol 1995; 42:1-218. https://doi.org/10.1385/089603-279-5:1.

[38] Gordis L. Assessing the validity and reliability of diagnostic and screening tests. In: Gordis L, editor. Epidemiology. 2nd ed. Philadelphia: Saunders; 2000. p. 63-81.

[39] SAS. (2013). The SAS system for Windows, release 9.4. In Cary, North Carolina, USA: SAS Institute Inc.

[40] Lacombe J, Mangé A, Solassol J. Use of Autoantibodies to Detect the Onset of Breast Cancer. J Immunol Res 2014; 2014. https://doi.org/10.1155/2014/574981.

[41] Tan HT, Low J, Lim SG, Chung MCM. Serum autoantibodies as biomarkers for early cancer detection. FEBS J 2009; 276(23):6880-6904. https://doi.org/10.1111/j.1742-4658.2009.07396.x.

[42] Kazarian A, Blyuss O, Metodieva G, Gentry-Maharaj A, Ryan A, Kiseleva EM, et al. Testing breast cancer serum biomarkers for early detection and prognosis in pre-diagnosis samples. $\mathrm{Br} \mathrm{J}$ Cancer 2017; 116(4):501-508. https://doi.org/10.1038/bjc.2016.433.

[43] Ye X, Ling B, Xu H, Li G, Zhao X, Xu J, et al. Clinical significance of high expression of proliferating cell nuclear antigen in non-small cell lung cancer. Medicine (Baltimore) 2020; 99(16):e19755. https://doi.org/10.1097/MD.0000000000019755.

[44] Malkas LH, Herbert BS, Abdel-Aziz W, Dobrolecki LE, Liu Y, Agarwal B, et al. A cancer-associated PCNA expressed in breast cancer has implications as a potential biomarker. Proc Natl Acad Sci U S A 2006; 103(51):19472-19477. https://doi.org/10.1073/pnas.0604614103.

[45] Hanash SM, Pitteri SJ, Faca VM. Mining the plasma proteome for cancer biomarkers. Nature 2008; 452(7187):571-579. https://doi.org/10.1038/nature06916.

[46] Chapman C, Murray A, Chakrabarti J, Thorpe A, Woolston C, Sahin U, et al. Autoantibodies in breast cancer: Their use as an aid to early diagnosis. Ann Oncol 2007; 18(5):868-73. https://doi.org/10.1093/annonc/mdm007. 
[47] Evans RL, Pottala J V., Nagata S, Egland KA. Longitudinal autoantibody responses against tumorassociated antigens decrease in breast cancer patients according to treatment modality. BMC Cancer 2018; 18(1):1-9. https://doi.org/10.1186/s12885-018-4022-5.

[48] Yilmaz MT, Elmali A, Yazici G. Abscopal Effect, From Myth to Reality: From Radiation Oncologists' Perspective. Cureus 2019; 11(1): e3860. https://doi.org/10.7759/cureus.3860.

[49] Suppiah A, Greenman J. Clinical utility of anti-p53 auto-antibody: Systematic review and focus on colorectal cancer. World J Gastroenterol 2013; 19(29):4651-4670.

https://doi.org/10.3748/wjg.v19.i29.4651.

[50] Zalcman G, Schlichtholz B, Trédaniel J, Urban T, Lubin R, Dubois I, et al. Monitoring of p53 autoantibodies in lung cancer during therapy: Relationship to response to treatment. Clin Cancer Res 1998; 4(6):1359-1366.

[51] Takeda A, Shimada H, Nakajima K, Imaseki H, Suzuki T, Asano T, et al. Monitoring of p53 autoantibodies after resection of colorectal cancer: Relationship to operative curability. Eur J Surg 2001; 167(1):50-53. https://doi.org/10.1080/110241501750069828.

[52] Firestein G, Budd R, Gabriel S E McInnes I B and O'Dell J. Kelley's Textbook of Rheumatology - 9th Edition. Elsevier 2013. https://www.elsevier.com/books/kelleys-textbook-of-rheumatology/9781437717389.

[53] Azami A, Suzuki N, Azami Y, Seto I, Sato A, Takano Y, et al. Abscopal effect following radiation monotherapy in breast cancer: A case report. Mol Clin Oncol 2018; 9(3):283-286. https://doi.org/10.3892/mco.2018.1677.

\section{Figures}




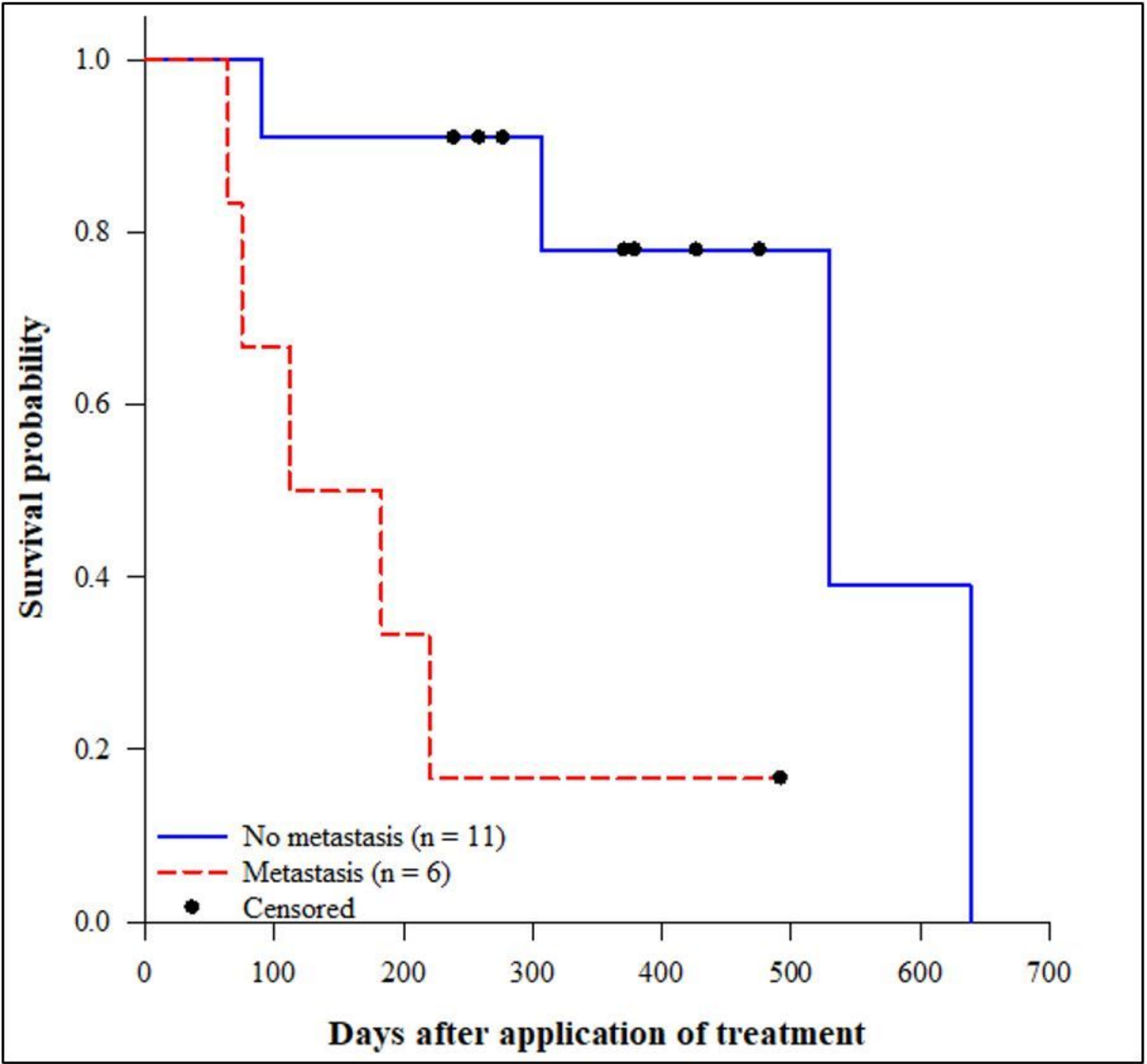

Figure 1

Effect of metastasis on survival probabilities of cats with mammary tumors 


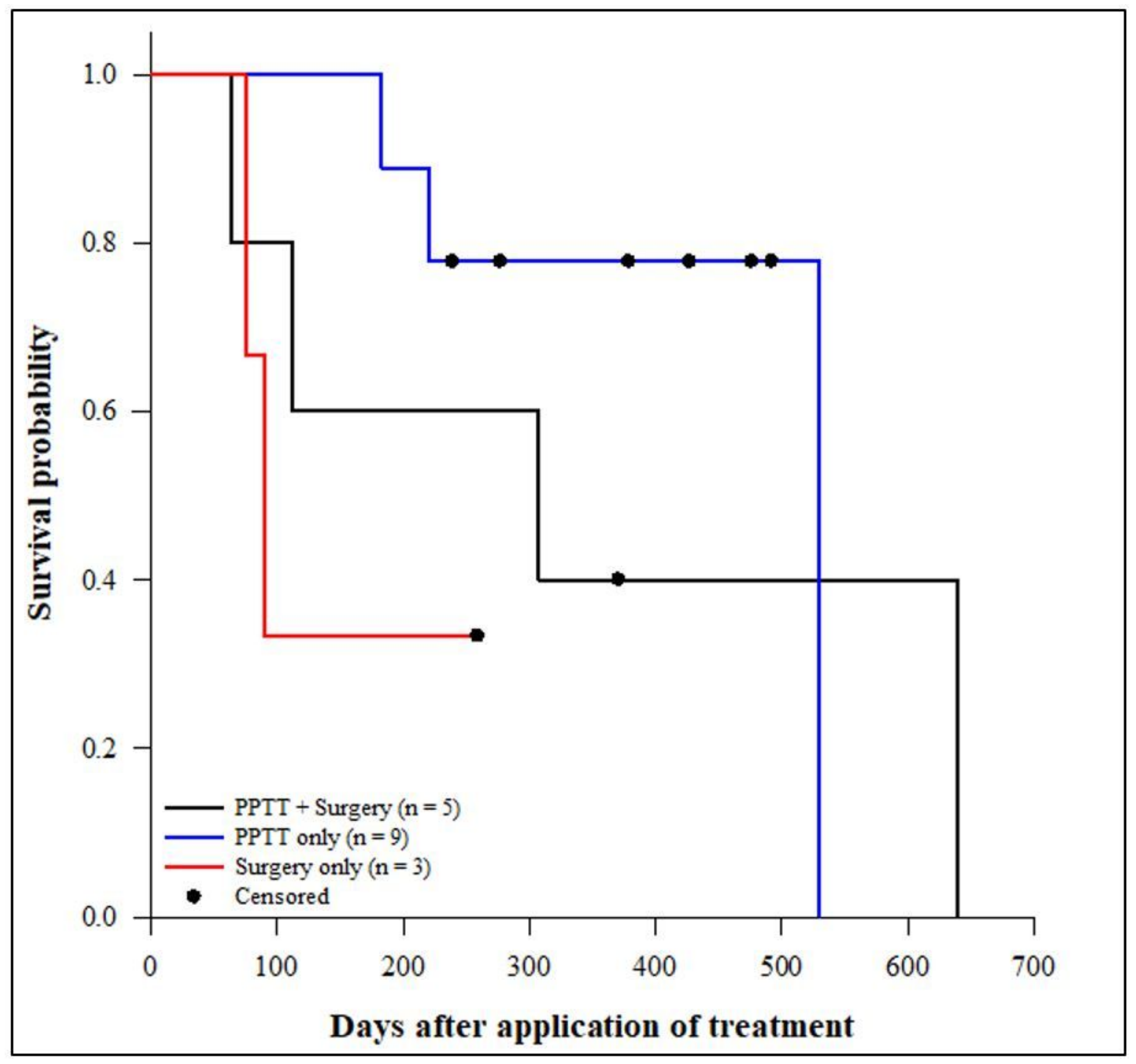

Figure 2

Effect of treatment on survival probabilities of cats with mammary tumors 


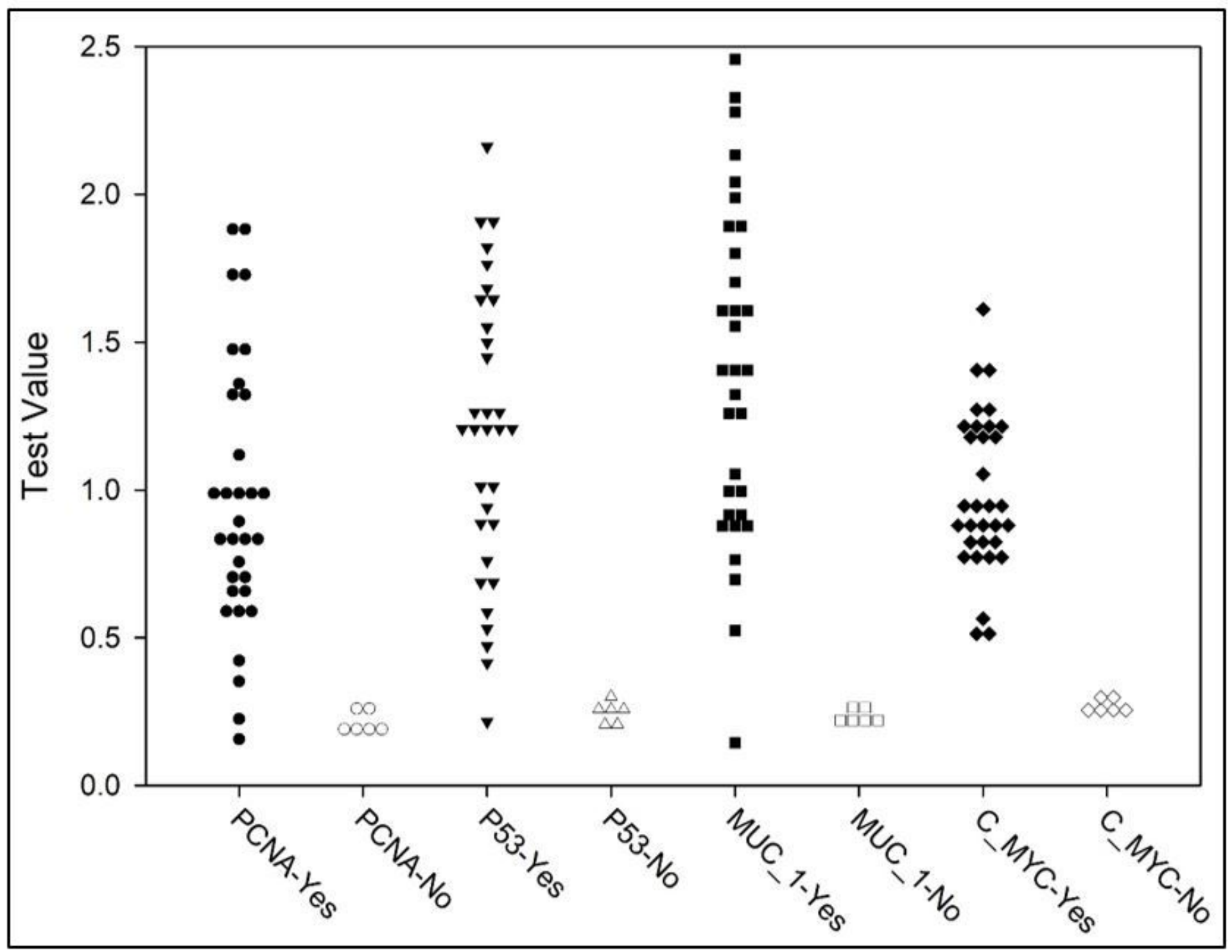

Figure 3

Measured values of four studied AAbs for six normal cats (No; white-filled symbols) and 32 cats diagnosed with mammary tumor (Yes; black-filled symbols) before application of any treatment. 


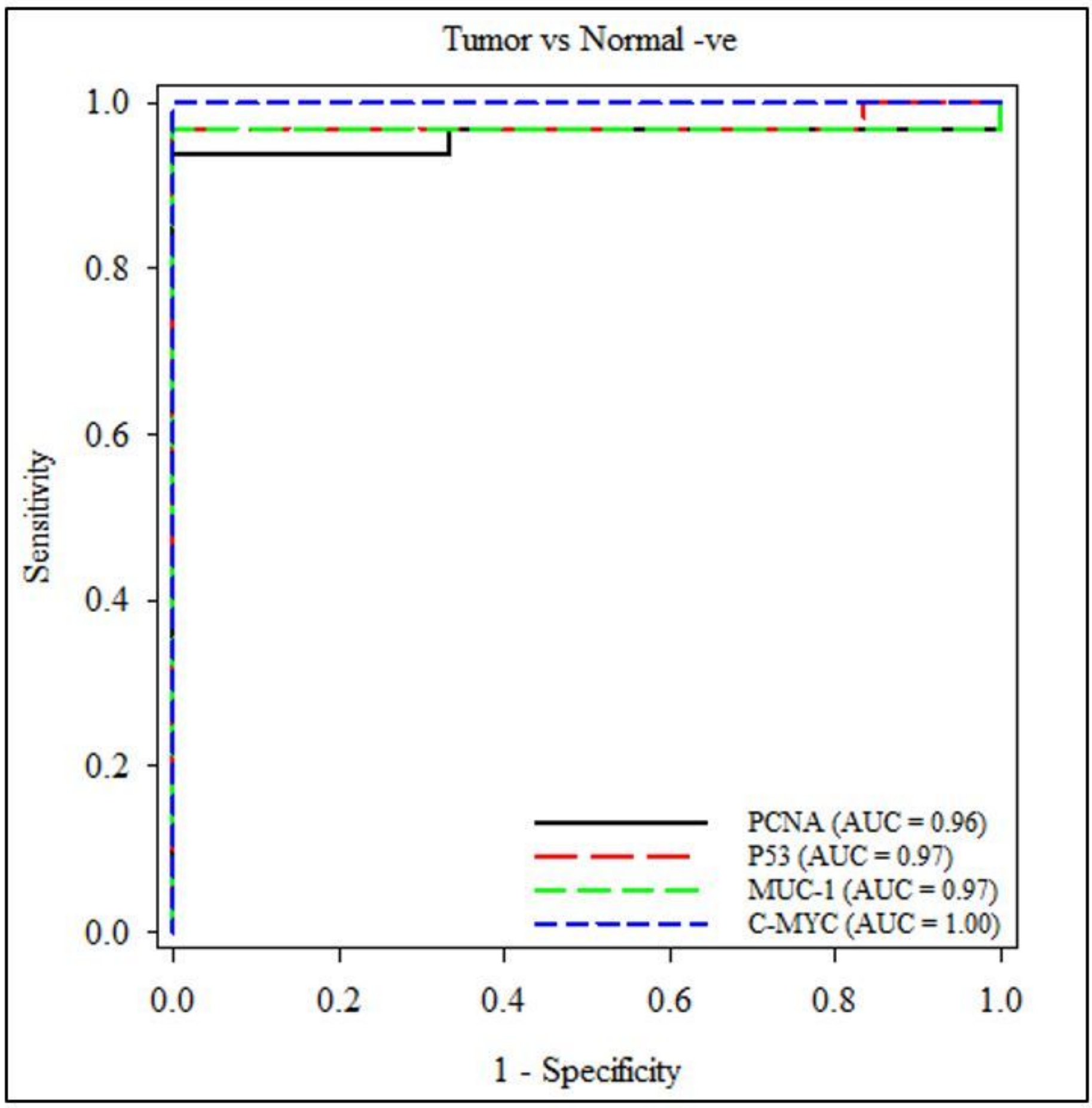

Figure 4

Comparison of receiver operating characteristic (ROC) curves of four different AAbs in mammary tumor detection 


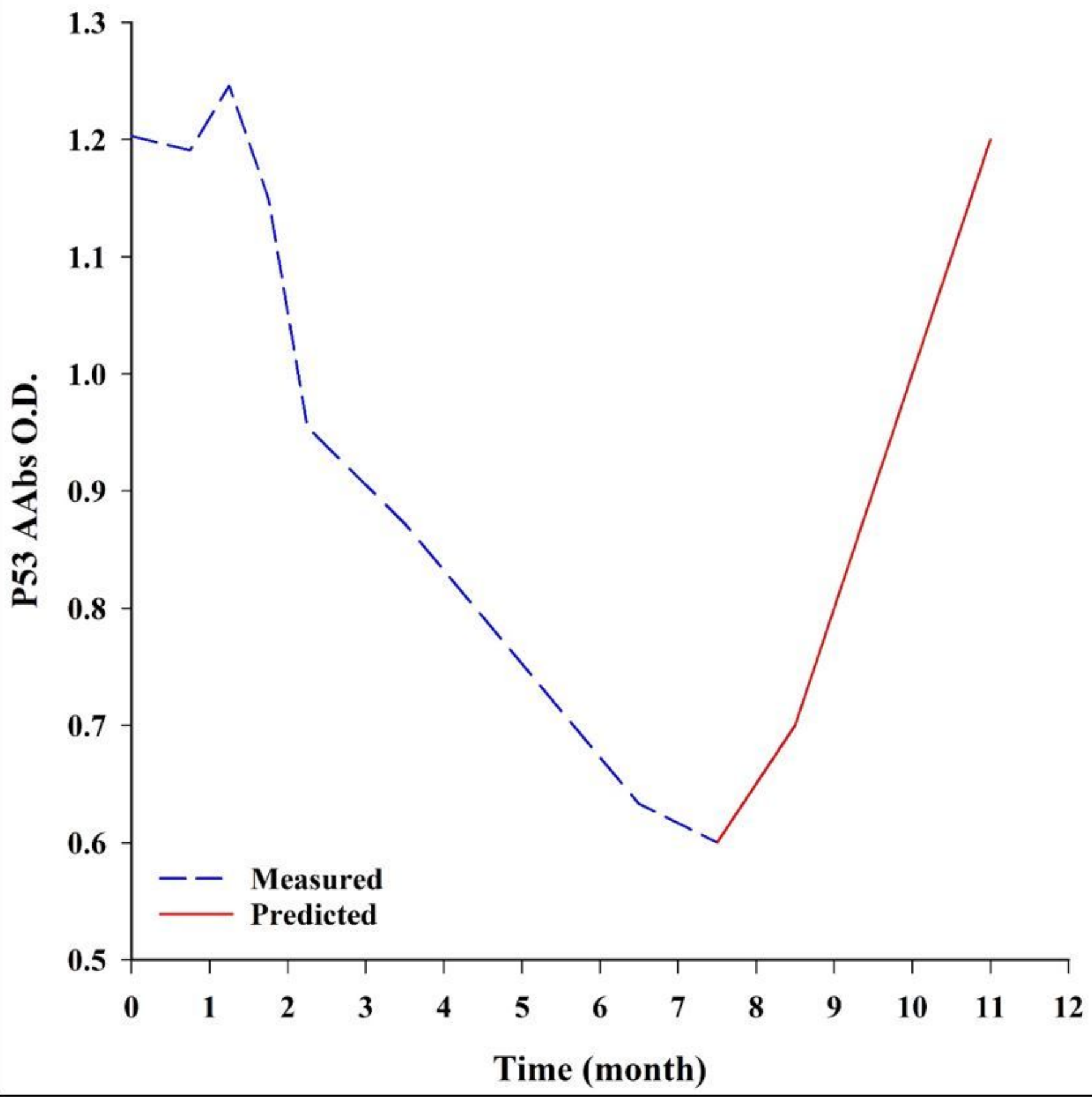

Figure 5

Measured and predicted values of P53 in a cat with a mammary tumor. The intersection between measured and predicted values marks the end of the PPTT treatment course.

\section{Supplementary Files}

This is a list of supplementary files associated with this preprint. Click to download. 
- combinationcases.docx

- PPTTcases.docx

- surgeryonlycases.docx 